\title{
ZAGŁADA WIDZIANA ZZA OCEANU
}

\author{
SŁAWOMIR BURYŁA*
}

\section{Z WOJNIŁOWA DO NOWEGO JORKU}

Nie tylko przeciętny czytelnik, ale i zawodowy krytyk miałby dziś problem z przypomnieniem sobie postaci i dzieła Sydora Reya. Trudno jest w słownikach czy kompendiach naukowych znaleźć jego biogram. Zamieszczają go Wspótcześni polscy pisarze i badacze literatury. Ale i to opracowanie, choć rzetelne, nie jest zbyt bogate w informacje. Oto czego dowiadujemy się o Reyu po roku 1939: „W kwietniu 1939 wyjechał do Stanów Zjednoczonych i zamieszkał w Nowym Jorku. Wiersze i prozę publikował na łamach pism polonijnych, m.in. »Robotnika Polskiego« (1939) i »Świtu« (1945). W 1945-1947 był współpracownikiem Polskiej Agencji Prasowej w Nowym Jorku. Następnie prowadził antykwariat, którego był właścicielem. Kontynuował twórczość literacką, publikując w 19571976 wiersze i prozę w londyńskich »Wiadomościach«. Był członkiem PEN Club Center for Writers in Exile. Dalszych informacji biograficznych brak" ${ }^{1}$. Nie udało się ustalić daty śmierci Reya. Jego powojenną aktywność twórczą oddaje dość ogólnikowa uwaga, że w latach 1957-1976 zamieszczał teksty poetyckie oraz fragmenty prozatorskie w londyńskim tygodniku Mieczysława Grydzewskiego. Tam też (od 1962 do 1966) drukowano kolejne rozdziały nieukończonej powieści Ludzie miejscowi ${ }^{2}$. Na stronie redakcyjnej tomu poetyckiego pt. Własnymi słowami (wydanego w roku 1967 sumptem Oficyny Poetów i Malarzy) czytamy: „Gotowe do druku: 1) Ludzie miejscowi, powieść, 2) Odzyskane dzieciństwo, zbiór opowiadań. W przygotowaniu: 1) Królestwo boże, szkic powieściowy i drobne utwory". Wymienione teksty nigdy nie ukazały się w formie książkowej. Syracuse University Librabry (USA) zawiera najbogatszą kolekcję

* Sławomir Buryła - prof. dr hab., Instytut Filologii Polskiej Uniwersytetu Warmińsko-Mazurskiego.

${ }^{1}$ Współcześni polscy pisarze i badacze literatury. Słownik biobibliograficzny, oprac. zespół pod red. J. Czachowskiej, A. Szałagan, Warszawa 2001, s. 39. Notabene ta ważna publikacja bibliograficzna nie odnotowuje w dorobku Reya Pieśni mówionych.

${ }^{2}$ Zob. „Wiadomości Literackie” 1962, nr 12, 20, 49; 1963, nr 21, 25, 30; 1964, nr 4, 19, 38 , 42, 46; 1965, nr 23, 28, 34, 41; 1966, nr 19. W zbiorach Polskiego Radia zachowało się nagranie dwudziestominutowej audycji z cyklu $Z$ warsztatu pisarza z 26 marca 1963 roku. Zawiera ono rozmowę z Sydorem Reyem na temat początków jego twórczości oraz grupy „Przedmieście”. Fragment Ludzi miejscowych czyta Aleksander Bardini. 
maszynopisów opublikowanych i nieopublikowanych fragmentów prozatorskich oraz poetyckich, zbiór korespondencji, wypowiedzi publicystycznych i krytycznoliterackich, materiałów biograficznych (w tym fotografii).

Stwierdzić, że Sydor Rey jest dziś autorem zapomnianym, to mimo wszystko wyrazić się niezbyt precyzyjnie. Należałoby bowiem najpierw wskazać moment, w którym - choćby na krótko - był znanym, czytanym. Jeśli wszakże uporczywie poszukiwać takiego okresu, to wypadałoby przywołać drugą połowę lat trzydziestych. Wtedy to urodzony w Wojniłowie na Podkarpaciu (dawne województwo stanisławowskie) Isak Reis ${ }^{3}$ wstąpił do Zespołu Literackiego „Przedmieście”. W 1936 roku ukazała się jego debiutancka powieść Kropiwniki ${ }^{4}$. To jeden z nielicznych tekstów realizujących w praktyce ideowe założenia „Przedmieścia”, zwracających się w stronę bohatera zbiorowego ze środowisk proletariackich nękanych przez biedę i brak pracy. Kropiwniki z pewnością znacząco powiększają zbiór - raczej skromnych - osiągnięć artystycznych grupy „Przedmieście”, ale na tle dokonań Dwudziestolecia nie należą do dzieł wybitniejszych ${ }^{5}$. To opowieść o typowym żydowskim sztetł na Kresach, która współczesnego odbiorcę może urzekać swym kolorytem. Dla nielicznych (pamiętających jeszcze czasy sprzed Zagłady) będzie ona miała wymiar głównie sentymentalny. Przywołuje bowiem obraz świata, którego już nie ma. Międzywojennemu sztetł Reya jednak wyraźnie bliżej do prozy Kalmana Segala, postrzegającej żydowską gromadę surowym okiem obserwatora problemów społecznych, niż do ujęć dziewiętnastowiecznych, gdzie tematyka społeczna - mimo iż coraz mocniej akcentowana - nie odgrywała jeszcze tak doniosłej roli. Dodatkowy kontekst Kropiwnikom - jak wielu innym utworom z epoki Dwudziestolecia traktującym o żydowskim sztetł - przydała Zagłada. Pojmował to również Rey, poprzedzając ich drugie wydanie (z 1962 roku) dedykacją: „Poświęcam teraz tę książkę pamięci członków mojej rodziny i pamięci mieszkańców Wojniłowa - ofiar wojen”. Tak oto powstał nagrobek. Nagrobek nieco wątpliwy. Kropiwniki bowiem to utrwalona piórem inteligenta pochwała proletariackiej mentalności, w takim samym stopniu, co krytyka pańskiego samolubstwa i buty. Pod pręgierz trafiła również żydowska tradycja oraz ortodoksyjna moralność rabinów, tak jak i wzniesiona na nich reli-

${ }^{3}$ Używał też innej formy nazwiska - Izydor Reiss.

${ }^{4}$ Kropiwniki doczekały się żywego zainteresowania krytyki: J. Andrzeje wski, „Prosto z Mostu” 1937, nr 2; E. B re ite r, „Wiadomości Literackie” 1937, nr 25; H. D o m ań sk i, „Droga” 1937, nr 7/8; A. Kruczkowski, „Pion” 1939, nr 29; J. Malaszewski, „Kultura” 1937, nr 37; A. Brylaszew sk i, Bohaterowie na mustrze, „Lwów Literacki” 1937, nr 3. Wydanie krajowe z 1962 roku omawiali: J. Wy ka, „Kropiwniki”, „Twórczość” 1957, nr 10/11; S. Wy g odzki, Po co komplikować sprawy oczywiste? „Nowe Książki” 1960, nr 6; Z. B i eńk k w s ki, Jeden z „Przedmieścia”, „Twórczość” 1963, nr 3; E. Solibors ka, „Kropiwniki” po latach, „Nowe Książki” 1963, nr 3. Debiut czasopiśmienniczy Reya przypada na rok 1929. W tygodniku „Świat, Dom i Szkoła" (nr 7/8) zamieścił opowiadanie Czarne listy podpisane pseudonimem Sydor Rey.

${ }^{5}$ Jerzy Kwiatkowski w monografii pt. Dwudziestolecie wymienia nazwisko Reya dwukrotnie, ani razu nie przywołując jego Kropiwników. 
gia judaistyczna. Po Shoah Rey mógł odbierać swoją buńczuczną postawę jako niesprawiedliwą wobec żydowskich współbraci. Zapewne o tej rysie na nagrobku myślał Rey w krótkim fragmencie Od Autora: „Sprawia mi szczególną radość fakt, że w dwadzieścia pięć lat po ukazaniu się pierwszego wydania tej książki, drugie wydanie ukazuje się dzięki delikatności wydawców bez zmian. Niejedno dałoby się w niej poprawić, i ja sam z trudem oparłem się pokusom. Poprawki znaczyłyby to samo, co wyretuszowanie po wielu latach młodzieńczego zdjęcia”. Mimo to obraz musi pozostać takim, jakim wyszedł spod bezkompromisowej, młodzieńczej ręki. Nie jest przecież winą Reya, że historia diametralnie zmieniła kontury sporządzonego portretu, przydając mu gorzki grymas. To, co wynikało z autentycznego poczucia krzywdy i objawiało się w ostrych przyganach wobec współczesności, wbrew intencjom twórcy nabrało wymiaru tragicznej drwiny.

Debiut Reya odnotował Witold Gombrowicz, słusznie wypominając wewnętrzne pęknięcia w powieści. Pisał nader przenikliwie w recenzji na łamach „Kuriera Porannego”: „Kropiwniki wprowadzają nas w sposób wielce autentyczny nie tyle w cierpienia mas pracujących, ile w bolączki pewnej grupy inteligencji żydowskiej, interesującej przez to, że łączy najbardziej skrajne przeciwieństwa. Rozpiętość takiego człowieka, jak Rey, jest rzeczywiście nadzwyczajna. Z jednej strony, pod względem społecznym - proletariat, i to proletariat najbardziej poniżony, bo żydowski; z drugiej - pod względem osobistym - niemal arystokratyczne uprzedzenia, duże i poważne aspiracje, nieprzeciętna inteligencja, na wielu punktach ogromne wysubtelnienie, wysiłek duchowy daleki od pospolitości. Co z tej mieszaniny wynika? Dziwoląg"6. Inaczej będzie w Rozbitkach, gdzie potrzeba rewolucji społecznej, podział świata na robotników i wyzyskiwaczy stracą na znaczeniu, a centralne miejsce zajmą cierpienia całej społeczności - niezależnie od statusu klasowego i majątkowego. Nim jednak dojdziemy do Rozbitków, należy zatrzymać się na chwilę przy poezji.

\section{POETYCKIE SILVA RERUM}

Wydane za życia Reya dwa wybory liryków: Pieśni mówione (Nowy Jork 1945)7 oraz Własnymi słowami (Londyn 1967) ujawniają materiał bardzo różnorodny, tak pod względem tematycznym, jak i poziomu artystycznego. Obok wierszy ciekawych, intrygujących pojawiają się słabsze. Reya zwykle gubią patetyczne i banalne konkluzje, niezbyt oryginalne metafory (np. Do matki, Drzewo).

W Pieśniach mówionych i zbiorze pt. Własnymi słowami znajdziemy przede wszystkim teksty oparte na tradycyjnej wersyfikacji. Tak jak i w prozie, Rey jest autorem zachowawczym, stroniącym od eksperymentu, podejmowania gry

${ }^{6}$ W. Gombrowicz, Drapieżny pisarz w potrzasku i zwycięstwie. Proletariacka huśtawka, „Kurier Poranny” 1936, nr 362. Przedr. Varia, t. 1, Kraków 2004, s. 220-221.

7 Wtórność i zapatrzenie w poetykę socrealistyczną zarzucał Pieśniom mówionym Marian Pankowski (Nowości poetyckie, „Kultura” 1957, nr 5). 
z odbiorcą. Oryginalne rozwiązania kompozycyjne, jak o tym przekonuje choćby Słownik nie słownik kolaż z przysłowi czy Szpieg, nie były jego domeną. Być może dlatego, że uświadamiały mu perspektywę utraty kontaktu z czytelnikiem, tak dla niego ważnym, stanowiącym o sensie bycia artystą.

W poetyckim dorobku Reya za najciekawsze, obok dzieł wykorzystujących siłę prostoty (np. Adam i Ewa, Po wojnie), uznać należy liczne stylizacje. Niemal wszystkie gromadzi tom pt. Własnymi słowami. Większość z nich odsyła do twórczości ludowej. Niektóre wprost wykorzystują znane przyśpiewki, powiedzonka (Mq̨dry, Uczony, O tym, jak pieśń ludowa wyprzedziła poezje surrealistycznq, Wolność słowa), inne sięgają po zastaną konwencję, by w niej umieścić nowe treści (Smak słowa i śmierci).

Własnymi słowami przełamuje podniosłą tonację Pieśni mówionych. Tragedia wojny, pamięć o losie najbliższych powraca jeszcze w elegijnym przebraniu (Cisza), niekiedy w nieporadnej emfazie (Wioska po wojnie, Życiorys), prostym wyznaniu (Po wojnie) albo zaskakującym użyciu mowy potocznej, z prozaizmami i wulgaryzmami (Ballada $z$ werblem). Coraz słabiej brzmi złowieszczy głos Zagłady. Przeważa inne ujęcie, w którym żałobną szatę zamieniono na strój po trosze błazna i mędrca, a po trosze domorosłego filozofa. Chce on przekazać czytelnikowi coś ze swego doświadczenia, ze swej gorzkiej (ale nie wiodącej do rozpaczy) wiedzy o świecie. To wiedza podana w filozoficznej otoczce, aurze refleksji, zadumy podszytej ironią, wolnej jednakże od przygnębiającej skargi (Po wojnie). Daje się w niej odnaleźć sporo przekory, nieco drwiny, trochę czarnego humoru, który bywa ich nieodłącznym towarzyszem (Pozazdrościć). Odżywa niepowtarzalny sens żydowskich przysłów i sentencji, w których smutek sąsiaduje z trudną radością. Piotr Matywiecki rozważając głębokie znaczenie mądrości żydowskiej, stwierdza, iż jest ona „oporem, jaki życie ludzkie stawia nadziei jako łatwej perspektywie, jak i bezwzględnemu, nihilistycznemu brakowi nadziei" ${ }^{8}$. Rey okazuje się interesującym aforystą. Niektóre z aforystycznych dokonań autora, przyjmują formę fraszki, dosadnej, na pograniczu dobrego smaku (Na plaży) albo wprost obscenicznej (Lepsza kurwa, Wielki pisarz). Osiąga przy tym lekkość i dystans do świata (Świadomość, Optymista, Pokusa, Pozazdrościć, Skarga), których trudno byłoby się spodziewać po Kropiwnikach, Pieśniach mówionych czy Rozbitkach. To - obok prostoty i ludowej stylizacji - bodaj najciekawsza z poetyckich propozycji.

Ta pobieżna analiza nie prezentuje bliżej wszystkich ważnych tematów w liryce Reya. Pomija chociażby powracającą tęsknotę za ojczyną (wzniosła Modlitwa uchodźcy, prostolinijny i smutny Ocean). Wypada jednak odnotować przynajmniej jedną kwestię. Chodzi o przedwojenną fascynację Reya komunizmem, która - nieznacznie zmodyfikowana - przetrwała Shoah. Czytamy w żarliwej Modlitwie (ze zbioru Pieśni mówione):

${ }^{8}$ P. Matyw ie cki, Dwa oddechy. Szkice o tożsamości żydowskiej i chrześcijańskiej, Warszawa 2010 , s. 51. 


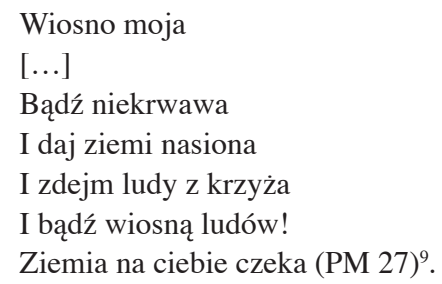

W poprzedzającym ją wierszu pt. Chleb równie żarliwie, choć nieco pretensjonalnie, brzmi fraza:

Najpierwszy jest krzyk robotnika głodnego

O chleb, którego nie dało mu niebo (PM 26).

Jest w niej naiwna, ale autentyczna wiara artysty w zdolność świata do transformacji w obliczu śmiertelnego zagrożenia (Wojna wiosny), w ocalającą moc idei pokoju (Życiorys), w zwycięstwo i chwałę nowego, lepszego świata (Tęsknota, Podkarpacie, Zmartwychwstanie). Zagłada nie podważyła przedwojennych przekonań Reya, Segala czy Stanisława Wygodzkiego. Wszyscy oni należeli do wyznawców marksistowskich haseł równości społecznej, zwolenników rewolucji ustrojowej. Dla Reya, Segala, Wygodzkiego bieda i nędza żydowskiej ulicy oraz antysemityzm poza nią okazały się decydujące w wyborze identyfikacji światopoglądowej. Widząc rozmiar zbrodni, dając jej literacki wyraz, jednocześnie zachowali wiarę $\mathrm{w}$ emancypacyjną siłę wyzwolenia z kapitalizmu. Idee marksistowskie w przypadku Reya czy Wygodzkiego nie przetrwały pod postacią bałwochwalczego kultu zinstytucjonalizowanych form komunizmu, ale w uznaniu dla sprawy ogólnoludzkiej. I taki jest też ich najgłębszy sens w poezji Reya.

\section{OPOWIEŚCI OCALONYCH}

W przywołanej recenzji pt. Proletariacka huśtawka Gombrowicz zastanawia się nad przyszłą drogą Reya jako prozaika. Jak powiada, najciekawsze są debiuty, gdyż stanowią autentyczną nowość, następne książki zwykle niewiele wnoszą do poetyki autora, nie zaskakują. Jednak w przypadku Reya mamy do czynienia ze złamaniem tej reguły. Po wyjeździe w 1939 roku do USA niedawny członek „Przedmieścia” diametralnie zmienia optykę ideową swej prozy. Jego Księge rozbitków (opublikowaną w kraju w 1959 roku) niewiele łączy z Kropiwnika$m i$. Niemal całkowicie znika proletariacka aura piętnowana przez Gombrowicza, wraz z walką klasową, banalną i nazbyt jednoznaczną konstrukcją antagonistycz-

${ }^{9}$ W tekście szkicu stosuję następującą formę skrótów, litery oznaczają cytowaną pozycję, cyfry - numer strony. Korzystam z wydań: K - Kropiwniki, Kraków 1962; PM - Pieśni mówione, Nowy Jork 1945; KR - Księga rozbitków, Warszawa 1959; WS - Własnymi słowami, Londyn 1967. 
nych postaci. Zagłada jakby przewróciła do góry nogami dawny świat, odmieniła i inaczej zaakcentowała jego problemy, umniejszyła stare dylematy społeczne. Rey porzuca zagadnienia społeczno-polityczne (choć jakiś ślad dawnych deklaracji światopoglądowych wciąż jest widoczny w Księdze rozbitków), by zmierzyć się z Shoah.

Księge rozbitków można nazwać zbiorem opowieści o Złotym Wieku i Katastrofie. Wydarzenia te zostały podniesione do rangi mitu. Uzyskały status punktu granicznego. Każdy z utworów da się umieścić na osi wyznaczonej przez dwa wektory czasu - prze d i po. Odpowiadają im dwie kategorie przestrzenne: tu i ta m. T u oznacza punkt obserwacyjny narratora. Jest nim Ameryka, do której przybył krótko przed Zagładą. Tam to oddalona o tysiące kilometrów Polska, a przede wszystkim rodzinne tereny narratora - Podkarpacie. Tak narrator, czytelnik, jak autor i jego bohaterowie nieustannie balansują między epoką przed i po, między Polską z „czarnych sezonów” a Ameryką. Oto podstawowy wymiar sytuacji komunikacyjnej w Księdze rozbitków. Poniekąd położenie narratora przypomina to, w jakim znajduje się dzisiejszy odbiorca nie mający biograficznego zakotwiczenia w epoce, o której traktuje Księga rozbitków. Rey obsadza narratora w roli ucznia, sztubaka wręcz, który próbuje się czegoś dowiedzieć o tym, co zaszło w Europie pod rządami nazistów. Katastrofa to czas, do którego narrator nie ma dostępu. Zdany jest na innych. Jego domenę stanowi świat sprzed Katastrofy. W Moim micie, będącym swoistym prologiem do Księgi rozbitków, śmierć matki wpisuje się w jeden z toposów literatury Holocaustu - motyw „dobrej śmierci". Takiej, która zastała Żyda przed Shoah, której nie zdołano ogołocić z kulturowych atrybutów. Jej zaprzeczeniem jest śmierć brata - anonimowa, samotna, taka, jaką chciał ją uczynić Holocaust.

W Rozbitkach Rey aktualizuje schemat egzystencjalno-epistemologiczny, który jako jeden z pierwszych w literaturze Holocaustu podjął Julian Tuwim w słynnym tekście $M y, \dot{Z} y d z i$ polscy... ${ }^{10}$ Wielki poeta analizuje w nim sytuację polskiego Żyda, który męczeńską śmierć współbraci obserwował zza oceanu. I choć porównanie z Tuwimem nie do końca jest adekwatne (Rey w swym skromnym dorobku literackim nigdy nie porzucił tematyki żydowskiej, nawet w dobie największego zauroczenia komunizmem), to w tym, co stanowi sedno zagadnienia, wypada odnotować istotne analogie. Nade wszystko Tuwima i Reya łączy poczucie winy wynikające z faktu, iż nie uczestniczyli bezpośrednio w cierpieniach narodu. Rodzi to potrzebę odkupienia, pokuty, a zarazem obawę, że nie jest się już częścią wspólnoty, że nie ma się do niej prawa. Dokonuje się swoiste samowydziedziczenie. Narrator Reya w obawie, że zostanie odrzucony, antycypuje własne lęki i dobrowolnie usuwa się na ubocze. Zamierza odpokutować „,zdradę”.

Nie jest to sytuacja nieznana literaturze Holocaustu. W opowiadaniu Wygodzkiego Zaraz - poczekaj - nie ma mężczyzna, który przeżył Zagładę poza Europą

${ }_{10}$ J. Tuwim, My, Żydzi polscy..., „Nowa Polska” 1944, nr 8. Przedr. Męczeństwo i Zagłada Żydów w zapiskach literatury polskiej, oprac. I. Maciejewska, Warszawa 1988. 
- w USA - powraca do Warszawy na ulicę Krochmalną. „Nie wyrozumiałości żądał, pragnął pokuty"11. Pogardza sobą: człowiekiem i artystą. Nie tylko pogardza, ale w jakimś samobójczym (masochistycznym) geście poszukuje miejsc, które staną się dla niego źródłem upokorzenia. Potrzeba ekspiacji jest niesłychanie potężna i jednocześnie wszechogarniająca. Zagarnia wszystko, każde doznanie z przeszłości, każde uniesienie, każdy poryw przeżyty bezpiecznie, z dala od krematoriów ma swoją cenę ${ }^{12}$. Trzeba spłacić dług sumienia. Jednak masochistyczne zapędy bohatera Wygodzkiego nie definiują w całości jego postawy. Zamierza - i to jest właściwy cel jego przyjazdu - namalować olbrzymi fresk, w którym utrwali obraz Krochmalnej. Chce na nim umieścić również siebie. Zapewne po to, by tym symbolicznym gestem dokonać pojednania ze społecznością, wśród której dorastał, spędził dzieciństwo i młodość. Myśl o tym nie opuszcza również narratora Ksiegi rozbitków.

Jest w zbiorze Reya znakomite zdanie, którego tragiczny sens ustawicznie powraca w literaturze Holocaustu (odnajdziemy je choćby w Doktorze Kleinie Adolfa Rudnickiego): „Odkąd zrozumiałem, że mi przypadło w udziale życie, właściwie odtąd postanowiłem żyć, odczułem samotność, której przedtem nie czułem, przedtem bowiem byłem związany z zamordowaną rodziną" (KR 99). Ocalenie okazuje się rodzajem skazania. Bohater Reya jest skazany na ocalenie bez możliwości odwołania, bez możliwości apelacji i bez szansy na wyżalenie się przed kimkolwiek. Charakterystyczne, że metafora rozbitków pojawia się nie tylko u Reya, choć - inaczej niż u Reya - zwykle odwołuje się ona do znanej opowieści biblijnej. Dzieje się tak między innymi w Końcu wojny Irit Amiel: „W Częstochowie zbierają się szybko ostatni rozbitkowie z Arki Noego. Powinni być szczęśliwi, ale nie są. Dopiero teraz zaczynają zdawać sobie sprawę, że choć przedtem wszyscy byli skazani na śmierć, to teraz skazano na życie tylko tych, co się jej wymigali"13.

Truizmem będzie stwierdzenie, że w biografiach ocalałych przeszłość zajmuje prymarną pozycję. Literatura Holocaustu sporo uwagi poświęca temu zagadnieniu. Większość autorów bez wahania uznałaby zapewne za swoje zdanie Giorgio Agambena: „Powołaniem ocalałego jest pamiętanie, ocalały nie może nie pamiętać"14. Pamięć przeniesiona zostaje w sferę powinności etycznej. Ale to zaledwie jeden jej wymiar. Przymus pamiętania niekoniecznie musi mieć charakter etyczny. W najbardziej podstawowym i powszechnym sensie pamięć łączy się z niemożnością wyeliminowania z umysłu ofiary przerażających obrazów,

${ }^{11}$ S. Wy god zki, Zaraz - poczekaj - nie ma [w:] Nauczyciel tańca, Warszawa 1963, s. 13.

12 „Odpokutować zadowolenie, spokój, niewiedzę i wiedzę o kwiatach i pszczołach, którą posiadł [...]; odpokutować dom, rodzinę, posiadanie żony i dwojga dzieci, córki i syna; odpokutować blask lampy, stwarzający wrażenie spokoju; odpokutować milczące przedmioty, wszystkie godziny spędzone w domu i w górach, w odludnych miejscach, wśród drzew, gdzie brał przychylne mu kobiety [...]" (Ibidem, s. 13).

${ }^{13}$ I. A mi e 1, Koniec wojny [w:] Podwójny krajobraz, Warszawa 2008, s. 10.

${ }^{14}$ G. A g a m be n, Co zostaje z Auschwitz, przeł. S. Królak, Warszawa 2008, s. 25. 
wokół których ustawicznie krążą jej myśli. Napastliwość obrazów z przeszłości sprawia, że - jak w niektórych opowiadaniach Reya - staje się ona jedyną realną rzeczywistością. „Zbudować teraźniejszość? - pyta jedna z postaci Mezaliansu Violi Wein. - Cóż to za pojęcie, trzeba ten czas wykreślić z gramatyki! Nie ma czegoś takiego, nie ma życia w czasie teraźniejszym" ${ }^{15}$. Powstaje zadziwiająca sytuacja, w której ceną za ocalenie jest egzystencja pomiędzy fałszywym istnieniem a autentycznym losem ${ }^{16}$. Bogdan Wojdowski stan ten definiuje następująco: „Ale jak tu nie wspominać, kiedy - tak naprawdę, tylko przeszłość istnieje"17. Jedynie ona jest czymś doniosłym, czymś, co dla ofiary ma znaczenie i wartość. Ukryty paradoks takiego widzenia uchwycił Jan Błoński, komentując znany utwór Wojdowskiego pt. Ścieżka: „Prawdziwa jest tylko przeszłość, ale prawda przeszłości jest koszmarem, triumfem śmierci i zła..."18. Tak właśnie, koszmarem i triumfem śmierci.

Dosyć wymowne okazuje się konsekwentne milczenie Reya na temat winy ocalonych. Temat, który niejednokrotnie odżywa na kartach poezji i prozy dotyczącej Zagłady jest prawie nieobecny w Księdze rozbitków ${ }^{19}$. Rey zgadza się w tej materii z Julianem Stryjkowskim. W słynnym tekście Stryjkowskiego $\mathrm{Na}$ wierzbach... nasze skrzypce znajdujemy zdanie: „Ci, co przeżyli, są święci, i Bóg ukarze rękę, która się na nich podniesie. Ci, co cudem ocaleli, nie mogą podlegać sądowi, człowiek nie ma prawa ich sądzić"

Narrator Reya próbuje przyjąć status ofiary. Jest to punkt, wokół którego zamierza zbudować swoją żydowską tożsamość. Jak Tuwim, chce poczuć się częścią wspólnoty cierpiących. Za Jeanem Améry gotów też powtórzyć, iż „odnalazł siebie w obrazie żydowskiej ofiary" ${ }^{21}$. Rodzi to znane obawy, z którymi swego czasu musiało zmierzyć się państwo Izrael22. Jak bowiem stworzyć coś stabilnego i silnego wokół wyobrażenia o narodzie tchórzy, o przysłowiowych owcach idących potulnie na śmierć? ${ }^{23}$ Rey nie podejmuje tych zagadnień. Albo inaczej: niejako wyprzedza sądy współczesnych, sakralizując cierpienia ofiar. Ocaleńcy z Zagłady to dwudziestowieczni święci. Zmaltretowane ciało Stelli domaga się

15 V. Wein, Mezalians, Olsztyn 1996, s. 48.

16 Zob. A. Molisak, Judaizm jako los. Rzecz o Bogdanie Wojdowskim, Warszawa 2004, s. 305 .

${ }^{17}$ B. Wojd ow ski, Pascha [w:] Krzywe drogi, Warszawa 1987, s. 8.

18 J. Błoński, Autoportret żydowski, czyli o żydowskiej szkole w literaturze polskiej [w:] Biedni Polacy patrzq na getto, Kraków 2008, s. 153.

${ }_{19}$ Prawie, bo Artur z Lekarza przyjmuje dotykającą go ślepotę jako karę za to, że „sam ocalał, a żona i córeczka zginęły w Krakowie z rąk hitlerowców..." (KR 183).

20 J. Stryjk ow sk i, Na wierzbach... nasze skrzypce [w:] Syriusz, Warszawa 1984, s. 258.

21 J. A méry, Poza winq i karq, przeł. R. Turczyn, Kraków 2007, s. 21.

${ }^{22}$ Zob. na ten temat m.in. obszerne opracowanie Idith Zertal, Naród i śmierć. Zagłada $w$ dyskursie i polityce Izraela, przeł. J. M. Kłoczowski, Kraków 2010.

${ }^{23} \mathrm{Z}$ uproszczeniami związanymi z tym stereotypem polemizowałem w szkicu Bojaźliwy jak Żyd w książce Opisać Zagładę (Wrocław 2006). Zob. też G. Kołac z, Czasami trudno się bronić. Uwarunkowania postaw Żydów podczas okupacji hitlerowskiej w Polsce, Warszawa 2008. 
czci (Stella i Wasylcio). Tak samo jak Felicji. „Mąż bał się jej dotknąć, jak gdyby w tym było coś brutalnego i bluźnierczego; jej męczeńskie ciało onieśmielało go" (KR 76). Onieśmiela też narratora.

Takie widzenie ocaleńców wydaje się zgodne z powszechnymi odczuciami, z dostępną nam wiedzą na temat psychologicznych mechanizmów reakcji na stres. Mniej oczywista, przeciwna potocznej obserwacji, jest inna postawa, o której słyszymy między innymi w opowiadaniach Ziemia i Nekrofilia. Choć jawi się jako bulwersująca i obrazoburcza, to w jakimś stopniu jest naturalna i zrozumiała. Nie jest przecież niczym niezwykłym, że osoby poddane ogromnemu ciśnieniu czynników zewnętrznych, wystawione na długotrwałe działanie stresu, chcą jak najszybciej zapomnieć, pozbyć się uciążliwych obrazów z przeszłości, jedynej szansy upatrując w poddaniu się wszechwładnemu prawu życia. Wiemy z biografii byłych więźniów obozów koncentracyjnych - chociażby Stanisława Grzesiuka - że po wyzwoleniu zachłannie próbowali oni nadrobić stracone lata. Bohater Daniela Irit Amiel po wyjściu z obozu ma dokładnie sprecyzowany cel: „Nie powracać nigdy do przeszłości. Najadać się do syta. Zrobić fortunę. Zwiedzić świat. I noc w noc omdlewać w ramionach najpiękniejszych kobiet"24. Narratora Nekrofilii razi swobodny sposób bycia Jadwigi. Postrzega go jako nie licujący z tragedią, której doświadczyła, jako profanację ofiar i ich cierpienia. Jadwiga nie zamierza mu się tłumaczyć. Nie czuje się też winna. Nie dość tego, prowokacyjnie pyta: czy ma jej za złe, że przeżyła? Czy to, że udało się jej przetrwać, ma dowodzić jej winy? Ocalenie jest raczej argumentem za niebywałą wytrwałością, heroizmem i odwagą. Ci którzy wyszli cało z Zagłady to herosi, a nie winowajcy.

Pozostaje więc chwytanie dnia, nadrabianie straconych chwil. Michał z Wesela $w$ Waszyngtonie mówi wprost, iż ,żałoba to dla nas jakby dalszy ciąg naszej męki..." (KR 30). Wygląda to tak jakby ocaleńcy zamierzali poprzez ekstatyczne doświadczanie egzystencji anihilować przeszłość. To jednak nie zawsze się udaje. Pełna werwy, optymizmu Jadwiga z Nekrofilii umiera pod koniec opowiadania. Zbyt mocno przylgnęła do życia. Zbyt zachłanne było w niej pragnienie raju, którego namiastkę otrzymała w Ameryce. Nazbyt mocno ją odurzył. Musiała odejść, bo w jej relacji do świata zabrakło półtonów, rejestrów pośrednich. Przepaść pomiędzy krainą śmierci, z której wyszła, a życiem była tak olbrzymia, że nie dała się pokonać jednym skokiem, jednym gestem. Przeszłość ma swoje prawa i nie można jej łatwo unieważnić.

Sygnalizowana w tytule tomu metafora ,rozbitków” odnosi się w takim samym stopniu do żydowskich ocaleńców z Europy, jak i do narratora. Również i on jest tym, którego zawierucha wojenna wyrzuciła samotnego na brzeg. On także utracił najbliższych, a dwa ostatnie zdania Prologu odniesione do jego sytuacji mają w sobie tyle samo zgryźliwej ironii, jak w stosunku do tych, którzy

${ }^{24}$ I. A mi e 1, Daniel [w:] Osmaleni, Izabelin 1999, s. 32. 
doświadczyli Shoah bezpośrednio: „Moją najwybitniejszą cechą jest to, że żyję; podczas gdy moja rodzina, przyjaciele, znajomi zginęli, ja ocalałem. Ci, którzy o tym wiedzą, rdzenni Amerykanie i inni, mówią: »To pan ma szczęście«...” (KR 5). I właśnie owa ambiwalencja szczęścia i kary dobitnie charakteryzuje sytuację narratora. Między „rozbitkami” z Europy a nim jest jednak zasadnicza różnica. Ci pierwsi z reguły uciekają przed demonami pamięci, on zaś nieustannie poszukuje choćby najmniejszych śladów tego, co się działo w Polsce. Dla „rozbitków” i dla narratora pamięć jest piętnem, z tą oczywiście różnicą, że w pierwszym przypadku okrutna przeszłość znajduje się poza sferą wyboru jako część biografii, a w drugim stanowi przedmiot świadomych zabiegów.

W Stelli $i$ Wasylciu zapoznajemy się z nieco dziwacznym przejawem nonkonformizmu głównego bohatera, kiedy nie dbając o siebie, zamierza uszczęśliwić Stellę, proponując jej małżeństwo. Stelli bowiem, jako tej, która tak wiele wycierpiała w okupowanej przez nazistów Polsce, należy się wszystko, co dobre i piękne. Tylko narratorowi, który „przeżył w Nowym Jorku”, ,wśród wygód” nie wolno niczego żądać. On odebrał już swoją nagrodę - nie musiał patrzeć na to, co Stella.

Narrator Stelli $i$ Wasylcia postępuje wzorem innych, którzy w założeniu rodziny widzieli panaceum na zszarpane nerwy i rozbitą psychikę ocalałych. Po wojnie jednym z częściej praktykowanych sposobów zapominania było założenie nowej rodziny. Samotne kobiety, samotni mężczyźni łączyli się w pary na innych zasadach niż przed Zagładą. Wiek, wygląd, fascynacje erotyczne nie odgrywały tak wielkiej roli, jak nadrzędna potrzeba przezwyciężenia dojmującego poczucia pustki. Samotność razem z natrętnie powracającymi myślami o okrutnym losie najbliższych miała właściwości destrukcyjne. Prowadziła jeśli nie do śmierci samobójczej to do stanu niebezpiecznego wyalienowania. Miłość przybierała postać lęku przed opuszczeniem, przed samotnością. Małżeństwo stanowiło więc antidotum na truciznę dobywającą się z największego europejskiego cmentarza. W Masce pośmiertnej narodziny dziecka stanowią dowód nie tylko potwierdzający fakt ocalenia, ale - co ważniejsze - nadają mu sens. Jedyną, dostępną formą odrodzenia jest więc pozostawienie po sobie potomstwa. Dlatego też finalne zdanie-sąd narratora o Kamilu (,Jak upiornie, samotnie, strasznie na własną musiał on rękę ocaleć, niby przeciw prawom historii...”, KR 97) nie ma już tak przygnębiającej wymowy. Odnosi się przede wszystkim do przeszłości, a teraźniejszość chwyta częściowo. Bardziej konstatuje to, co było niż ukazuje przyszłość (której znakiem jest w tekście dziecko bohatera).

Propozycje ślubu odrzuca również Jadwiga. Małżeństwo, szczęście rodzinne byłoby zdradą, nie tyle wobec ofiar, co wobec siebie, wobec straszliwej wiedzy, jaką wyniosła z wojny. Niewykluczone, że ma w tym swój udział także świadomość bycia napiętnowanym, kimś, kogo dusza jest tak diametralnie różna od tego, kto nie przeżył Zagłady, że nie ma szansy na jakiekolwiek porozumienie.

Jest jeszcze inna droga ucieczki od przeszłości. To błogosławieństwo niepamięci. „Na szczęście nie wszystko pamiętam...” (KR 15) - deklaruje Michał 
z Wesela w Waszyngtonie. Chciałoby się zapytać: „Jak niewiele?” Czy możemy jednak wierzyć bohaterowi? A nawet jeśli weźmiemy za dobrą monetę jego słowa, to pozostaje wątpliwość, do czego odnosi się pojęcie „niewiele”. Czy idzie o zasięg (w znaczeniu ilości utrwalonych zdarzeń), czy o głębię (a raczej powierzchowność) ich utrwalenia.

Nigdy nie uda się autorytatywnie orzec, czy deklaracje ofiar są prawdziwe, a mówiąc precyzyjniej, czy nie wchodzi w grę jakiś rodzaj samooszukiwania się, wyparcia. Czy wolno nam wierzyć bezkrytycznie Januszowi z Handlarza sztuki, o którym czytamy, że do swej wojennej biografii ,nie przywiązywał [...] żadnej wagi" (KR 79). Nonszalancja, z jaką podchodzi do tych czasów, może być formą obrony, maskowania się przed „impertynencją” rozmówcy, o którym wiadomo, że nie zna z autopsji ,epoki pieców”. Nie należy z tego czynić zarzutu interlokutorowi Janusza, bo przecież nie ma żadnej pewności, że indagowany zechciałby coś więcej powiedzieć, że zdecydowałby się wyjść poza dezynwolturę, z jaką spogląda na traumatyczne wydarzenia z przeszłości. A że nie tak łatwo się ich pozbyć, że wbrew życzeniom ofiar wciąż stanowią one żywe (dotkliwe) dziedzictwo, przekonuje Michał z Wesela w Waszyngtonie. Zdradza się przed narratorem, gdy z rozbrajającą szczerością oznajmia, iż z obrazu świata przedwojennego nie zostało w nim nic. Widzimy, jak niekłamane, autentyczne jest w nim pragnienie powrotu w wyobraźni do czasów sprzed Katastrofy. Nabiera ono wymiaru niemal fizycznego łaknienia. Nie bez powodu słyszymy takie oto wyznanie: „we mnie wszystko wyschło...” (KR 24). Życie w perspektywie permanentnej destrukcji jest niemożliwością. Zachwianie równowagi między bodźcami pozytywnymi a negatywnymi ze wskazaniem na te ostatnie prowadzi do poważnych zaburzeń. Dlatego prośba Michała nie ma nic z nostalgicznej pogoni za dawnymi krajobrazami, za wspomnieniem minionych dni, poznanych ludzi. To sprawa e g z y s te n c ja ln a, sprawa życia i śmierci.

Znany temat syndromu ocalonego pojawia się więc u Reya wyłącznie w związku z osobą narratora (i autora). Zażenowanie, wstyd, jakie odczuwa w kontaktach z ,rozbitkami” ani na moment nie odstępują narratora, stawiając go w pozycji kogoś gorszego ex definitione. „Ja im zazdrościłem, że doświadczyli czegoś, czego ja nigdy nie doświadczę, i o tyle pozostanę poniżej nich" (KR 16). Uratowani z ognia Zagłady obezwładniają: ,Ta jego głęboka nieruchomość i milczenie onieśmielały mnie, odbierały wszelki sens moim słowom” (KR 17). Prowadzi to do swoistego kompleksu tego, który przeżył bezpiecznie za oceanem wobec tych, którzy znaleźli się w centrum masowego mordu. Znamienne, że wśród jego elementów konstytutywnych nie ma po wielokroć podnoszonego problemu braku reakcji (albo niedostatecznej reakcji) diaspory amerykańskiej na los europejskich Żydów ${ }^{25}$. „Winę” narratora należy rozpatrywać w indywidualnym wymiarze. Nie stoi za nią żaden kontekst polityczny. Nawet rodząca się w nim myśl o pomocy

${ }^{25}$ Zob. na ten temat. m.in. D. S. Wy ma n, Pozostawienie swemu losowi. Ameryka wobec Holocaustu 1941-1945, przeł. W. Sadkowski, Warszawa 1994. 
pozostaje indywidualną decyzją: „Przez długi czas po wojnie myślałem z ciężkim sercem o tym, że byłbym się mógł podczas wojny dostać drogą podziemną z Nowego Jorku do moich stron rodzinnych i tam przez udział w antynazistowskiej organizacji pomóc najbliższym [...]” (KR 102). Czysto prywatny, niemal intymny charakter uczuć narratora potwierdzają relacje łączące go z większością ocalonych. Są pośród nich dawni znajomi, dawne, młodzieńcze miłości. Wszyscy wywodzą się z miasteczka, w którym i on się urodził. Tym samym do kompleksu narratora dochodzi dodatkowy czynnik - nie tylko uniknął on cierpień, jakie spadły na współplemieńców, ale biernie obserwował.

Narrator Reya nigdy i w niczym nie szuka usprawiedliwienia. Nie kryje się za parawanem „obiektywnych przyczyn”. Wina jest niewątpliwa. Zadaniem oskarżonego pozostaje tylko rozpoznanie jej najróżniejszych postaci. Dokonuje się ono w imię identyfikacji z „pogrążonymi”, by użyć określenia Primo Léviego ${ }^{26}$. Na nieustanne próby zbliżenia się do ofiar podejmowane przez narratora Marceli z opowiadania Ziemia patrzy ze współczuciem. Jak można trafić do świata pomordowanych współbraci? Jak - choćby częściowo - przedrzeć się do tego, co noszą w swej pamięci? Księga rozbitków bynajmniej nie łudzi nas wiarą w możliwość przeniknięcia wnętrza ocalonych, doświadczenia świata z „czarnych sezonów”. Nie pomogą pokora, dobre intencje i ciągłe kajanie się narratora. A jednak Rey wskazuje ścieżkę tym, którzy chcą dotrzeć do ocalonych. Jest nią szlak wyznaczany przez empatię. Rey wszakże - jak już powiedziano - nie wierzy w końcowy sukces. „Chciałem tylko obcować ze śmiercią, tak jak z nią obcowali pod okupacją hitlerowską moi najbliżsi, zanim zginęli. Chciałem, aby życie moje było narażone, ale żebym ani na chwilę nie wątpił, że ocaleję. Wyglądałem jak człowiek, który umiera, igrałem własnym życiem, jednak było w tym coś komedianckiego - czytałem to oczach bliźnich" (KR 44). To, co tragiczne, niepostrzeżenie przechodzi w komiczne. Nie da się dotrzeć do tamtych ludzi i tamtych straszliwych dni, spoglądając z naszej, bezpiecznej strony, którą oddziela od nich sytuacja historyczna i społeczna, nieporównywalna z tamtą. Możemy współczuć ofiarom, pochylać się nad ich bólem, ale bez nadziei na jego uobecnienie. Nam, którzy nie doświadczyliśmy piekła Holocaustu, pozostaje jedynie onieśmielenie, bezradność i współczucie.

Próżno szukać u Reya refleksji metaliterackiej nad literaturą i jej zdolnością do wyrażania sytuacji granicznych. Autor nie zmienia swego warsztatu, nie poddaje go rewizji. Pozostaje wierny konwencji realistycznej, rozbudowanej jednakże - w stosunku do Kropiwnik - o aurę tajemniczności. Pytania o język jako medium komunikacyjne zostają uchylone, a dokładniej rzecz ujmując - w ogóle nie pojawiają się w polu refleksji. Ich namiastkę zawiera Anioł stróż, z którego dowiadujemy się, że ocaleni ,prawie nigdy nie mówili o zamęczonych dzieciach, ani o własnych, ani obcych” (KR 145). Czy dlatego, że cierpienie kilkuletniego

26 P. Lé vi, Pograżeni i ocaleni, przeł. S. Kasprzysiak, Kraków 2007. 
dziecka, jego absolutna irracjonalność nie znajdująca wytłumaczenia w rzeczywistości, obezwładnia świadka? Czy nie przez to, że brakuje mu odpowiedniego języka, by oddać ogrom bólu? A może o tym decyduje blokada psychiczna, wciąż niepokojąco żywe wspomnienia?

Narrator Wesela w Waszyngtonie dyskredytuje ekspresywne słownictwo, którym Michał - jego przyjaciel - oddaje słynną amerykańską próbę atomową na atolu Bikini. Czyni to z przekonaniem o nieadekwatności tak skonstruowanego słownika wobec tragicznego wydarzenia. Okazuje się jednak, że językiem banału Michał posłużył się zamierzenie, dla ukazania blichtru wszelkich ,ładnych” formułek artystycznych. Czy to samo wolno powiedzieć o narratorze Reya? Oto dwa przykłady: „Znów wpatrywał się w przechodniów, ale tym razem nie zdawał się ich przenikać, tym razem zdawał się czegoś szukać w ich twarzach. Ale czego? Chyba zagubionych odłamków własnego życia” (KR 24); „Koleżanka płakała bezustannie, jej żarliwe, tkliwe słowa miały w sobie coś z modlitwy. To nie była jej pierwsza miłość, ale miłość pierwsza w swoim rodzaju i sile, w jej uczuciu decydującą rolę odgrywały przejścia wojenne Stelli, zmaltretowane ciało kobiece..." (KR 170). Obydwa passusy grzeszą zbytnią ekspresywnością, mimowolną ckliwością i utartą metaforyką (,,zagubione odłamki własnego życia”; „Koleżanka płakała bezustannie, jej żarliwe, tkliwe słowa miały w sobie coś z modlitwy”).

Sprawą zasadniczą dla Reya jest jednak nie brak języka, lecz wspólnego doświadczenia. Narrator zresztą przeczuwa, iż ocaleni nie mówią mu wszystkiego. W Weselu w Waszyngtonie ma nieodparte wrażenie, że brat coś przed nim ukrył: „List ten jeszcze bardziej pogłębił we mnie wrażenie, że Michał nie powiedział mi wszystkiego o czasach wojny i okupacji, że ukrył coś przede mną i prawdopodobnie rzeczy najistotniejsze" (KR 32). Powstaje nowy rodzaj wspólnoty, który przekracza więzy krwi i sprawia, że muszą one ustąpić przed swoistym rodzajem braterstwa, jakie ustanawia razem przeżyta gehenna obozów, getta, życia po aryjskiej stronie.

Również inny wielki temat literatury Holocaustu, refleksja o charakterze filozoficznym, spojrzenie na los Żydów w perspektywie pytań o kondycję kultury europejskiej nie należy do tych wątpliwości, które poruszają wyobraźnię Reya. Jest chyba tylko jedno proste wytłumaczenie tego faktu - rozważania takie przekraczały horyzont intelektualny pisarza. Brak pogłębionej analizy faszyzmu nie musi być jednak zarzutem, tym bardziej, jeśli przypomnimy sobie, ilu zdolniejszych i bardziej znanych twórców niż Rey popadało w banał, mierząc się z tą tematyką. Idzie wszakże o to, iż w tych nielicznych fragmentach, w których Księga rozbitków podnosi kwestię nazizmu, wchodzi automatycznie na płaszczyznę frazesu, nie potrafi uwolnić się od skonwencjonalizowanego i nieco przebrzmiałego wizerunku hitlerowskiego oprawcy.

W opowiadaniu Szulim zbrodniarz Heinecke ukazany jest jako narcystyczny efeb, który - pielęgnując w sobie wrażliwość na fizyczne piękno - jest zarazem zdolny do niebywałego okrucieństwa. Rey powtarza więc znany i spopularyzowa- 
ny obraz kata spajającego w jednej naturze bezwzględnego oprawcę i człowieka wrażliwego na sztukę ${ }^{27}$. Esteta z Szulima, wyczulony na piękno w każdej postaci, okazuje się wyjątkowo poręcznym narzędziem Zagłady: „Na takich estetów hitlerowcy liczyli w swej polityce eksterminacyjnej i aby im ułatwić misję, najpierw redukowali ofiary do poziomu obrzydliwego robactwa" (KR 130). Wszelkie ułomności, jakiekolwiek kalectwo, wszelką niedoskonałość należało eliminować, eliminując jej posiadacza. Tak oto estetyka zajmuje miejsce etyki. A Holocaust jawi się jako „kampania przeciw brzydocie” (KR 133). Następuje przy tym doryanowskie powiązanie występku ze szpetotą fizyczną: „Dokoła mordowano ludzi, a on brzydł, jakby każda śmierć padała na jego twarz...” (KR 133). Demoniczno-doryanowski Heinecke wypowiadający wojnę brzydocie zdaje się postacią w jakimś sensie nieprawdziwą, tworem stereotypowym, intelektualną konstrukcją, a nie kreacją tłumaczącą fenomen hitlerowskiego zbrodniarza. Rey nie tyle więc stara się zagadnienie przemyśleć, rozpoznać i przeniknąć, co raczej obudować „efektownymi” pomysłami na naturę oprawcy. Tym samym rzecz całą spłyca.

W Księdze rozbitków znajdziemy dwa opowiadania, które naruszają dominującą w całym tomie konwencję realistyczną. Nie są one jednak w żadnym wypadku prostym zaprzeczeniem zdroworozsądkowej wizji rzeczywistości. Chusta Naści poszerza realistyczną optykę o sferę mitu, Matka Hitlera penetruje zaburzenia stanu równowagi psychicznej. Tak w pierwszym jak i w drugim przypadku zachowane zostają reguły prawdopodobieństwa życiowego.

W planie fabularnym Chusta Naści relacjonuje dwie historie, które w pewnym momencie się ze sobą spotykają. Osamotniony narrator-bohater zamierza odnaleźć ślady po zamordowanej rodzinie. Udaje się więc do osób, o których wie, że pochodzą z jego stron. Tak oto trafia do Haliny, która - jak się okazuje - posiada zdjęcia nie tylko jego najbliższych, ale całe archiwum. Halina powiadamia go też o istnieniu tajemniczej chusty. Ukrainka Nastia, znachorka, wytarła nią twarz Nykoły Bardacha, Żyda, który się wychrzcił i przystał do grekokatolików. Niemal wszystko, co dotyczy chusty i jej cudownych właściwości, owiewa tajemnica, jest niejasne. Niektórzy - jak Aleksander Bardach - twierdzą, że Naścia otarła twarz Nykole oraz towarzyszącym mu w drodze na śmierć dwunastu rabinom. Inni, że tylko Nykole. Nie ma też zgody, co do tego, czyją podobiznę przedstawia chusta Naści. Każdy widzi tam kogoś ze swoich bliskich. Narrator, na przykład, dostrzega odbicie sióstr, braci, rodziców. Streszczona tu opowieść jednoznacznie odsyła do Nowego Testamentu. Chusta Naści to chusta świętej Weroniki, którą ta otarła twarz Chrystusowi tak, jak ukraińska chłopka Nykole i dwunastu rabinom prowadzonym na śmierć przez hitlerowców. Postać Nykoły można odczytać jako figurę Chrystusa. A skoro tak, to na utwór Reya wolno spojrzeć jak na kolejny inwariant ważnego dla literatury Holocaustu toposu Chrystusa współcierpiącego

${ }^{27}$ Ten dość znany wizerunek nazisty przywołuje Andrzej K u śn i e w i c z w Eroice oraz - nieudolnie - Bogdan Rutha w Szczurzym pałacu. W ostatnich latach obraz hitlerowca-dekadenta spopularyzował Jonathan Li t te 11 w powieści Łaskawe. 
z narodem wybranym. Charakterystyczny jest jednak sposób, w jaki Chrystus-Nykoła zamierza uratować współbraci. Udało mu się wymóc na rabinach, aby ci na czas prześladowań zwolnili wyznawców Jahwe z nakazów religijnych. Ma to być odpowiedź na bierną, wyczekującą postawę Najwyższego.

Historia chusty ma jeszcze jeden przełomowy moment. Skrywa pytanie o problem przedstawiania. Narrator początkowo w fotografii odnajduje najdoskonalszego pośrednika między nim a przeszłością: „,Myślałem o zdjęciach mojej rodziny [...] z religijnym żarem. Wszyscy moi bliscy byli na zdjęciach młodzi i piękni, a zatem nieśmiertelni; to nie było zmartwychwstanie, to była nieśmiertelność” (KR 108). Fotografia wszakże będąca „kładką nad czasem”28, niesie też pewne zagrożenia. Przede wszystkim ujednoznacznia obraz, unieruchamia w czasie reprezentację i zarazem narzuca nam ramę odbioru. To zaś kłóci się z przemyśleniami narratora, który pojmuje, że ,aby odzyskać przeszłość i zacieśnić kontakt z rzeczywistością nie wystarczy zebrać ślady własnej rodziny, człowiek musi wyjść daleko poza związki rodzinne” (KR 108). Chusta, której przygląda się społeczność sztetł, ma więc przewagę nad fotografią. Wymowny jest fakt, że to właśnie pozbawione wyraźnych konturów twarze z chusty mocno utkwiły w pamięci narratora, a nie wyraziste portrety ze zdjęcia.

Matka Hitlera - ostatnie i najdłuższe opowiadanie w Księdze rozbitków - jest być może najsłabszym tekstem w tomie. Kumuluje w sobie niemal wszystkie grzechy i mankamenty prozy Reya. Bywa rozwlekła, o zbytecznie rozbudowanych portretach postaci drugoplanowych, przez co czytelnik traci główny wątek opowieści. Zasadnicza idea bynajmniej nie zyskuje na klarowności, gubiąc się pośród kwestii mniej znaczących. Brakuje selekcji, konsolidacji treści, całość sprawia wrażenie dzieła niedopracowanego. Rey popełnia też inny znamienny dla niego błąd. Nie ufając zdolnościom interpretacyjnym czytelnika, stara się wszystko dopowiedzieć, wyjaśnić. Nużąca okazuje się również tendencja do budowania długich zdań. Brzmią one nieco anachronicznie. To wielosłowie gubi pisarza.

Matka Hitlera jest najbardziej „udziwnionym” utworem w Księdze rozbitków. Nie ma to oczywiście nic wspólnego z ekspansją fantastyki. Idzie o zjawiska znane psychiatrii. Młoda Amerykanka o imieniu Alice, piękna, inteligentna popada w szaleństwo i w pewnym momencie oznajmia narratorowi, że jest matką Hitlera. To kuriozalne wyznanie należy widzieć przez pryzmat jej biografii. Zawiera ona bowiem klucz do tych zagadkowych słów. Początków zaburzeń psychicznych wypada szukać w traumie, jaką dla Alice była samobójcza (?) śmierć ojca. Wydarzenie to głęboko przeorało psychikę bohaterki, naznaczyło rozlicznymi bliznami. Poczuła się obco w domu rodzinnym, pośród matki i brata. Chowała w sobie żal do matki za to, jak traktowała ona męża krótko przed śmiercią. Skompromitowana w oczach Alice instytucja małżeństwa i rodziny domagała się zastą-

${ }^{28}$ Nawiązuję do tytułu książki Michała Gło w iń s ki e g o Kładka nad czasem. Obrazki z Miasteczka (Kraków 2006). 
pienia jej czymś, co przekraczałoby ramy wyznaczone przez krąg najbliższych. Solidarność z ofiarami wojny była tym, co mogło zaspokoić potrzebę empatii, uczuciowego związku z pokrzywdzonymi. Związek tych uczuć z tragicznym odejściem ojca jest ewidentny: „Wojna i hitleryzm były dla niej polem zasłanym ciałami o poderżniętych gardłach, jak ciało ojca" (KR 198).

Żydowskie korzenie rodziny narratora stają się dla niej synonimem cierpień, jakie zrodziła zbrodnicza ideologia nazizmu. Pierwszy raz narrator zostaje przyjęty bezwarunkowo do wspólnoty ofiar. Charakterystyczne jednak, że do tej wspólnoty „zaprasza” go osoba, która sama nie doświadczyła bezpośrednio „,zasów pogardy". Bezpośrednio nie, ale czy nie można mówić o jakimś innym rodzaju więzi Alice z okrutną przeszłością starego kontynentu? Jakkolwiek jej życiorys nie zahacza w żadnym punkcie o II wojnę, to w dziejach rodziny odnajdujemy coś, co może rzucić nieco światła na postawę Alice. Dowiadujemy się z nich, że po przodkach od strony ojca płynie w niej niemiecka krew, a od rodziny matki ma domieszkę krwi węgierskiej i żydowskiej. Wiedza ta wywołuje u niej poczucie winy (jest przecież biologicznym dziedzicem rasy morderców). Jeśli jednak od tej strony spojrzeć na problem, to nie wolno zapominać, że jest w niej też jakiś element duszy żydowskiej. Zatem Alice ma również prawo do identyfikacji i z tą nacją. Winna więc postrzegać siebie jako tę, która potrzebuje pomocy. A jednak sprzeczność jest pozorna. Alice chce w ten sposób spłacić dług żydowskiej części samej siebie.

\section{ZAGŁADA WIDZIANA ZZA OCEANU}

W przypadku dzieł sięgających po temat Holocaustu pada często pytanie o powód, dla którego powstały. Wskazuje się wtedy na kilka racji. Zwykle w gronie możliwych odpowiedzi znajdziemy pragnienie świadczenia, ukazania prawdy o tym, co się stało, przestrogę moralną, utrwalenie pamięci o pomordowanych. Ida Fink, zastanawiając się nad genezą swojej twórczości, mówi: „Chciałam wydobyć ich z anonimowości, nadać im imię. Jakże często ginęły całe rodziny, nikt nie ocalał, nikt o nich nie pamiętał. Należało przywrócić im człowieczeństwo" ${ }^{29}$. Refleksje Fink są zapewne najbliższe genezie Księgi rozbitków, ale i inne wymienione wyżej przyczyny znajdują swoje uzasadnienie w tomie Reya. Żadna z nich - jakkolwiek ważna - nie dotyka jednakże kwestii fundamentalnej. Ksiega rozbitków - poza wszystkim innym i ponad wszystko inne - stanowi osobiste rozliczenie autora z przeszłością. W tej sytuacji słowo pisarza jawi się jako powiernik, a literatura jako powierniczka bólu. Jest nie tylko miejscem jego artykulacji, ale rezerwuarem cierpienia. Nigdzie i w żaden inny sposób przeszłość nie jest dostępna narratorowi opowiadań Reya, jak tylko w słowie. Przetworzona w literaturę staje się narzędziem między pamięcią ,rozbitków” a narratorem. Ale mediacja

${ }^{29}$ Imiona Zagłady. Z I. Fink rozmawia K. Masłowski [w:] Żydzi, Sowieci i my, Warszawa 2005, s. 58. 
to tylko jedna z dwóch funkcji literatury. Drugą, najpełniej i zgodnie z intencjami Reya, wyraziła swego czasu Jadwiga Maurer w Lidze ocalałych: „Chciałabym [...] zostać kronikarką miejsc, których nie było na mapie i wydarzeń, których nie odnotowała historia" 30 . Małych żydowskich miasteczek w Polsce, o których milczy Wielka Historia. Jej perspektywę bowiem wyznacza makroskala, artysta zaś widzi w mikroskali. Tylko tak może on pochwycić pojedynczy ludzki los.

Księga rozbitków jest próbą dotarcia do koszmaru Endlösung. Jej autor Zagładę znał tylko z relacji ocalonych. Jest to jeden z czynników, który sprawia, że opowiadania Reya jawią się nam jako wykoncypowane, nieautentyczne. Rey nieustannie zmierza w stronę sakralizacji ofiar, doznanych cierpień i okrucieństwa. Potrzeba uwznioślenia bólu i nieludzkich męczarni, które stały się udziałem żydowskich współbraci z Polski, wynikała zapewne z niekłamanego poczucia winy u Reya (opuścił on kraj krótko przed wybuchem wojny). Księga rozbitków winna być więc odbierana jako swoisty dług wobec pomordowanych i ocalonych. To dydaktyczne założenie okazało się zgubne dla tomu, który nie potrafi przekroczyć czarno-białej perspektywy w widzeniu „,czasów pogardy”. Skomplikowanie obrazu - załamanie klarownego podziału, w którym sfera zła jest wyraźnie odgrodzona od dobra - Rey postrzegałby zapewne jako przejaw zdrady wobec pomordowanych Żydów.

Fakt, iż Rey nie widział Zagłady sprawia, że Księga rozbitków w porównaniu z twórcami, którzy przeżyli Holocaust w Polsce a później wyjechali z kraju - jak Henryk Grynberg czy Jerzy Kosiński - wypada nieprzekonująco. Konwencje, do jakich odwoływali się Grynberg i Kosiński są wprawdzie krańcowo odmienne, jednak łączy ich wspólnota doświadczenia, przebywanie w bezpośrednim sąsiedztwie ognia Zagłady, które skutkowało równie sugestywnymi i porażającymi wizjami Shoah. Ale bezpośrednie doświadczenie rzeczywistości Shoah nie musi być czynnikiem rozstrzygającym i automatycznie przesądzającym o artystycznym sukcesie lub klęsce (choć w przypadku Reya oddalenie od Auschwitz jest elementem kluczowym, rzutującym na kształt całego tomu). Dowodem są opowiadania Zygmunta Haupta ze Szpicy (Lili Marlene, Perekotypołe, El pelele), Samael w niebie Stanisława Vincenza (pochodzący z Tematów żydowskich). Zagłada ominęła Leo Lipskiego, a przecież jego proza należy do najbardziej niezwykłych i najciekawszych literackich przetworzeń tego zdarzenia. Poza Polską - najpierw w strefie okupacyjnej we Lwowie, a potem w głębi Związku Radzieckiego - z dala od hitlerowskiej machiny eksterminacji przetrwał wojnę Julian Stryjkowski. Mimo to udało mu się udźwignąć temat Holocaustu. Trzeba jednak pamiętać, że Stryjkowski - za wyjątkiem kilku dzieł (zgromadzonych w zbiorach Na wierzbach nasze skrzypce... i Imię własne) - nigdzie nie odwołuje się wprost do Shoah. Posiłkuje się za to przemilczeniem, supozycją, fabularną nieobecność Zagłady zastępując rekonstrukcją atmosfery nadciągającej Katastrofy.

${ }^{30}$ J. Ma ure r, Liga ocalałych, Londyn 1970, s. 123. 
Równie wiele (jeśli nie więcej) można podać przykładów artystów, którzy przeszli przez piekło „epoki pieców”, ale nie byli w stanie zbudować spójnej i autentycznej wizji Zagłady. Bliskość zdarzenia niekiedy onieśmielała i wiodła ku banalnym konstatacjom myślowym i utartym konstrukcjom artystycznym. Sprawą fundamentalną jest więc skala talentu twórcy. Reya gubi przede wszystkim „literackość” Księgi rozbitków - zbyteczna i niekiedy chybiona metaforyka. Styl Żydowskiej wojny czy Zwycięstwa Grynberga jest oszczędny, lakoniczny i ironiczny zarazem (przez co tak wstrząsający). Podobnie Józef Mackiewicz w znakomitym reportażu Ponary-Baza w wizerunku beznamiętnej twarzy oprawcy przedstawia kwintesencję masowej zbrodni na Żydach. I Grynberg, i Mackiewicz odrzucają poetykę krzyku, żalu i rozpaczy. Przemawiają przez zwięźle, ale wyraziście podane fakty. Ale reportażowa narracja nie była jedyną konwencją, w jakiej wypowiadała się proza emigracyjna o Holocauście. Eksploatowała ona różnorodne środki wyrazu - wyrosłe z odmiennych tradycji (na przeciwnym biegunie do Mackiewicza należałoby bowiem umieścić Podzwonne dla dzwonnika Gustawa Herlinga-Grudzińskiego). Łatwo wszakże zauważyć różnicę w poziomie umiejętności literackich między Reyem a Grynbergiem czy Mackiewiczem (świadkami Shoah) z jednej strony, oraz Hauptem i Herlingiem-Grudzińskim - jako tych, którzy nie byli w centrum Zagłady - z drugiej.

Widzenie zza oceanu wprawdzie zacierało i deformowało obraz, ale mocą artystycznego talentu udawało się niekiedy pokonać te przeszkody (My, Żydzi polscy... Juliana Tuwima czy zapomniany esej Tymona Terleckiego Alle Juden raus...) $)^{31}$. Rey nie rozporządzał jednak zdolnościami pisarskimi na miarę rzeczywistości, o której usłyszał i o której chciał świadczyć.

\section{Stawomir Buryła}

THE HOLOCAUST FROM THE TRANSATLANTIC PERSPECTIVE

Summary

This article is concerned with the life and work of Sydor Rey. It focuses on Rey's volume of short stories entitled Castaways, taking it as a reference point for a series of comparisons of the way in which Polish writers in exile who had to rely on second-hand accounts tried to represent the experience of the Holocaust.

31 Ostatnio przypomniał go Kazimierz A d a m c zy k. Zob. te g o ż „Alle Juden raus...”- Tymona Terleckiego głos samotnego chrześcijanina [w:] Doświadczenia polsko-żydowskie w literaturze emigracyjnej (1939-1980), Kraków 2008. 